\section{Incidence of Rio Grande Gummosis of Grapefruit Is Not Associated with Concentrations of Anions in Soil Water}

Y.C. Li

University of Florida, Institute of Food and Agricultural Sciences, Tropical Research and Education Center, 18905 SW 280 Street, Homestead, FL 33031

A.K. Alva

University of Florida, Institute of Food and Agricultural Sciences, Citrus Research and Education Center, 700 Experiment Station Road, Lake Alfred, FL 33850

D.V. Calvert, R.M. Sonoda, R.R. Pelosi, and D.J. Banks

University of Florida, Institute of Food and Agricultural Sciences, Indian River Research and Education Center, 2199 South Rock Road, Fort Pierce, FL 34945

Additional index words. Citrus paradisi, chloride, fertilizer, irrigation, plant disease

Abstract. The objective of this study was to evaluate the role of chloride $\left(\mathrm{Cl}^{-}\right)$and other anions in soil water on the incidence and severity of Rio Grande Gummosis (RGG) in grapefruit (Citrus paradisi MacFadyen) trees. White 'Marsh'grapefruit trees on sour orange ( $C$. aurantium Lush.) rootstock were grown on two-row raised beds. Due to differential rates of $\mathrm{K}$ application (as $\mathrm{KCl}$ ), the trees received various rates of $\mathrm{Cl}^{-}$ranging from 0 to $156 \mathrm{~kg}^{\prime} \mathrm{ha}^{-1}$ per year. Soil water was sampled using suction lysimeters at 120 - and 180-cm depths. The severity of RGG was evaluated 18 months following the application of various rates of $\mathrm{KCl}$. The concentration of $\mathrm{Cl}^{-}$in soil water samples varied from 16.2 to 617 $\mathrm{mg} \cdot \mathrm{L}^{-1}$, with mean concentrations across all treatments of 160.7 and $188.4 \mathrm{mg} \cdot \mathrm{L}^{-1}$ for 120 and $180-\mathrm{cm}$ depth water samples, respectively. The concentrations of $\mathrm{Cl}^{-}$and other anions $\left(\mathrm{NO}_{3}^{-}, \mathrm{PO}_{4}^{3-}, \mathrm{SO}_{4}^{2-}\right)$ in soil water at either $120-$ or $180-\mathrm{cm}$ depth were poorly related to the incidence or severity of RGG $(R=-\mathbf{0 . 1 0}$ to $-\mathbf{0 . 2 8})$. Chloride concentrations in the soil water ranged from 20 to $617 \mathrm{mg} \cdot \mathrm{L}^{-1}$ near the RGG-free trees, and from 16.7 to $310 \mathrm{mg} \cdot \mathrm{L}^{-1}$ near the trees that were affected by RGG. This suggests that under the conditions of this study, neither the incidence nor the severity of RGG was influenced by high concentrations of $\mathrm{Cl}^{-}$ in the soil water.

Rio Grande Gummosis (RGG) of grapefruit (Citrus paradisi MacFadyen) trees is a widespread problem in the East Coast region of Florida. The disease generally affects trees over 20 years of age. A survey of 18 grapefruit groves showed that $3 \%$ to $74 \%$ of the trees (white and red varieties) were affected by RGG (Hebb and Sonoda, 1992). The trees with severe symptoms become progressively less productive and eventually die. The cause of RGG is not clear; however, several hypotheses have been proposed. Davis (1980) provided evidence that infection with Diplodia natalensis (Pole-Evans) could induce gummosis symptoms. However, the relationship between RGG and $D$. natalensis is yet to be clearly established (Childs, 1953,

Received for publication 19 Nov. 1997. Accepted for publication 30 Mar. 1998. Florida Agricultural Experiment Station Journal Series no. R-05344. This study was made possible by a grant from St. Johns River Water Management District and South Florida Water Management District. The cost of publishing this paper was defrayed in part by the payment of page charges. Under postal regulations, this paper therefore must be hereby marked advertisement solely to indicate this fact. 1978a; Olsen, 1952; Sonoda and Pelosi, 1992). Lee et al. (1994) compared healthy trees and RGG-affected trees and found that psorosislike agents were present in the RGG-affected trees. However, they were unable to prove conclusively that RGG was caused by psorosis. Calvert (1973) and Childs (1978a) provided some evidence for greater incidence of RGG in trees fertilized with $\mathrm{KCl}$ than in those fertilized with $\mathrm{K}_{2} \mathrm{SO}_{4}$. Childs (1978b) surveyed 10 grapefruit groves and suggested that the incidence of RGG tended to be greater in trees with levels of leaf chloride in the range of 154 and $S(n=104)$. to $498 \mathrm{mg} \cdot \mathrm{kg}^{-1}$. In contrast, a study using 20 year-old 'Marsh' grapefruit trees with four treatments and only one replication (Russo et al., 1993) revealed no significant differences in leaf $\mathrm{Cl}$ concentration between RGG-affected trees fertilized with $\mathrm{KCl}\left(278-373 \mathrm{mg} \cdot \mathrm{kg}^{-1}\right)$ and RGG-free trees fertilized with $\mathrm{K}_{2} \mathrm{SO}_{4}(362$ $\left.\mathrm{mg} \cdot \mathrm{kg}^{-1}\right)$. Therefore, the role of $\mathrm{Cl}$ in the incidence and severity of RGG remains unclear. The objective of this study was to determine the effects of the short-term elevation of $\mathrm{Cl}^{-}$ and other anions in soil water on the incidence and severity of RGG in grapefruit trees.

\section{Materials and Methods}

This experiment was conducted in a commercial grove with 26-year-old white 'Marsh' grapefruit trees on sour orange ( $C$. aurantium Lush.) rootstock in Martin County, Fla. An area of $\approx 8$ ha was surveyed in 1993 for tree health and uniformity. All of the trees chosen for the experiment had no symptoms of RGG. Five healthy and uniform trees were selected for each plot. The experiment involved two irrigation treatments as main plots: 1) irrigation at low moisture depletion, i.e., tensionmeter set point at 10-15 kpa, and 2) irrigation at high moisture depletion, i.e., tensionmeter set point at 20-25 kpa. Fertilizer treatments were subplots. The fertilizer applied was $6 \mathrm{~N}-1 \mathrm{P}-6.1 \mathrm{~K}$ at rates of $0,466,933$, 1866 , and $2800 \mathrm{~kg} \cdot \mathrm{ha}^{-1}$, with $\mathrm{K}$ supplied as $\mathrm{KCl}$ to provide annual rates of $\mathrm{Cl}$ application at $0,26,52,104$, or $156 \mathrm{~kg} \cdot \mathrm{ha}^{-1}$. All treatments were replicated four times. Suction lysimeters were installed at two depths $(120$ and $180 \mathrm{~cm})$ at $120 \mathrm{~cm}$ from the tree trunk along the tree line. Soil water samples were collected from suction lysimeters at 2 -week intervals. The concentrations of chloride $\left(\mathrm{Cl}^{-}\right)$, nitrate $\left(\mathrm{NO}_{3}^{-}\right)$, sulfate $\left(\mathrm{SO}_{4}^{2-}\right)$, and phosphate $\left(\mathrm{PO}_{4}^{3-}\right)$ were determined using a Dionex 500 Ion Chromatography (Dionex Corp., Sunnyvale, Calif.). The application of treatments began in Apr. 1994, and water sampling and anion analysis began in Aug. 1994.

\section{Results and Discussion}

Soil water was sampled 26 times between Aug. 1994 and Sept. 1995. The concentration of $\mathrm{Cl}^{-}$varied from 16.2 to $617 \mathrm{mg} \cdot \mathrm{L}^{-1}$ depending on treatment, with mean concentrations across all treatments of 160.7 and $188.4 \mathrm{mg} \cdot \mathrm{L}^{-1}$ for 120 - and $180-\mathrm{cm}$ depth water samples,

Table 1. Correlation coefficients between concentration or ratio of anions in soil water at 120 -cm depth, and 1) Rio Grande Gummosis (RGG) of grapefruit trees, 2) irrigation rate, and 3) rates of application of $\mathrm{Cl}$, $\mathrm{N}, \mathrm{P}$, and $\mathrm{S}$, and between severity of $\mathrm{RGG}$ and 1) irrigation rate and 2) rate of application of $\mathrm{Cl}, \mathrm{N}, \mathrm{P}$,

\begin{tabular}{lcccccr}
\hline \hline & $\begin{array}{c}\text { Severity } \\
\text { of RGG }\end{array}$ & $\begin{array}{c}\text { Irrigation } \\
\text { rate }\end{array}$ & \multicolumn{4}{c}{ Rate of application of: } \\
\cline { 5 - 7 } & & & $\mathrm{Cl}$ & $\mathrm{N}$ & $\mathrm{P}$ & $\mathrm{S}$ \\
\hline Concentration of anions & -0.20 & -0.07 & 0.33 & & & \\
$\mathrm{Cl}^{-}$ & -0.10 & -0.01 & & 0.22 & & \\
$\mathrm{NO}_{3}^{-}$ & -0.11 & 0.22 & & & 0.21 & \\
$\mathrm{PO}_{4}^{3-}$ & -0.28 & 0.05 & & & & 0.11 \\
$\mathrm{SO}_{4}^{2-}$ & 0.20 & -0.18 & -0.07 & 0.01 & 0.29 & 0.20 \\
Ratio of $\mathrm{Cl}^{-}$to all anions & \\
Severity of $\mathrm{RGG}$ & --- & 0.14 & -0.12 & -0.12 & -0.23 & -0.02 \\
\hline & ${ }^{2}$ Ratio $=\left[\mathrm{Cl}^{-}\right] /\left[\mathrm{Cl}^{-}+\mathrm{NO}_{3}^{-},+\mathrm{PO}_{4}^{3-},+\mathrm{SO}_{4}^{2-}\right]$ & & & & &
\end{tabular}


respectively. Irrigation did not influence the concentration of any of the ions monitored in the soil water at the 120 (Table 1) or $180-\mathrm{cm}$ depth (data not shown). As expected, application of $\mathrm{Cl}$ increased $\mathrm{Cl}^{-}$concentrations at 120 cm depth $(R=0.33, P=0.01)$ but had no effect at the $180-\mathrm{cm}$ depth (data not shown).

On 12 Sept. 1995, the trees were examined for symptoms of RGG. The severity of the symptoms was ranked on a scale of 0 to $5(0=$ no RGG symptoms and $5=$ severe symptoms). A total of $26 \%$ of the trees showed symptoms of RGG and the severity of RGG for affected trees ranged from 0.5 to 4.0 with the mean of 1.5. Regression analysis of the data indicated that the concentrations of $\mathrm{Cl}^{-}$and other anions $\left(\mathrm{NO}_{3}^{-}, \mathrm{PO}_{4}^{3-}, \mathrm{SO}_{4}^{2-}\right)$ in soil water at either 120 or $180 \mathrm{~cm}$ (data not shown) depth were poorly related to the incidence or severity of RGG $(R=-0.10$ to -0.28$)$ (Table 1). Chloride concentrations in the soil water ranged from 20 to $600 \mathrm{mg} \cdot \mathrm{L}^{-1}$ near the RGG-free trees, and from 16.7 to $310 \mathrm{mg} \cdot \mathrm{L}^{-1}$ near the trees that were affected by RGG. There was some improve- ment in the relationship between the severity of RGG and soil water $\mathrm{Cl}^{-}$when $\mathrm{Cl}^{-}$was expressed as a ratio of $\mathrm{Cl}^{-}$to other anions. However, the correlation coefficient was still very low $(R=0.20)$. Irrigation rates and rates of ion application were also poorly related to the incidence or severity of RGG $(R=-0.23$ to 0.14 ) (Table 1). Therefore, under the conditions of this study, neither the incidence nor the severity of RGG was influenced by high concentrations of $\mathrm{Cl}^{-}$in the soil water.

\section{Literature Cited}

Calvert, D.V. 1973. Response of 'Marsh' grapefruit trees in the Indian River area to potassium application-Yield and fruit quality. Proc. Fla. State Hort. Soc. 86:13-19.

Childs, J.F.C. 1953. An actinomycete associated with gummosis disease of grapefruit trees. Phytopathology 43:101-103.

Childs, J.F.C. 1978a. Rio Grande gummosis of citrus trees. Part II. The causal relations of Rio Grande gummosis. Plant Dis. Rptr. 62:395-399.
Childs, J.F.C. 1978b. Rio Grande gummosis of citrus trees. Part I. A brief review of the history and occurrence of Rio Grande gummosis. Plant Dis. Rptr. 62:390-394.

Davis, R.M. 1980. Evidence for the involvement of Diplodia natalensis in Rio Grande gummosis of citrus. J. Rio Grande Valley Hort. Soc. 34:5560.

Hebb, J.R. and R.M. Sonoda. 1992. For Florida grapefruit growers: Is gummosis becoming more of a problem? Citrus Ind. 73:28-29.

Lee, R.F., C.A. Powell, R.R. Pelosi, and R.M. Sonoda. 1994. Psorosis-like agents prevalent in Rio-Grande gummosis-affected Ruby red grapefruit groves and grapefruit budwood sources. Proc. Fla. State Hort. Soc. 107:13-14.

Olson, E.O. 1952. Investigations of citrus rootstock disease in Texas. Proc. Rio Grande Valley Hort. Inst. 6:28-34.

Russo, L.W., H.K. Wutscher, and F.W. Bistline. 1993. Effects of three water sources on the incidence of Rio Grande gummosis in grapefruit groves. Proc Fla. State Hort. Soc. 106:35-37.

Sonoda, R.M. and R.R. Pelosi. 1992. Comparing Rio Grande gummosis and citrus blight incidence on grapefruit on Swingle citrumello rootstock. Proc. Fla. State Hort. Soc. 105:28-32. 